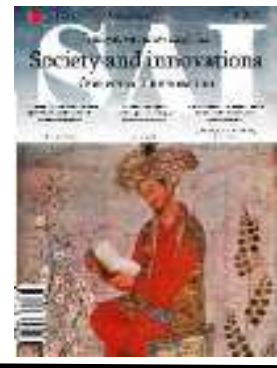

\title{
Development of enterprise products in students - as a factor of production problems for young enterprises
}

\section{Lutfulla UBAYDULLAEV ${ }^{1}$ Fotima ERGASHEVA ${ }^{2}$}

Namangan Engineering and Technological Institute, Namangan, Uzbekistan

\begin{tabular}{l} 
ARTICLE INFO \\
\hline Article history: \\
Received January 2021 \\
Received in revised form \\
15 January 2021 \\
Accepted 20 February 2021 \\
Available online \\
7 March 2021 \\
\\
\hline Keywords: \\
Youth \\
Entrepreneurship \\
Youth entrepreneurship \\
Entrepreneurial skills and \\
abilities \\
Peculiarities of \\
entrepreneurial activity \\
Support for the development \\
of youth entrepreneurship \\
Research \\
Problems \\
Recommendations
\end{tabular}

ABSTRACT

The development of youth entrepreneurship is one of the important issues in the field of youth employment. Today, among young people, there is a great desire for self-employment, and they try to independently support themselves financially. The article shows the share of young people in the population of our country, the share of young entrepreneurs in the structure of entrepreneurs. In the course of the study, we analyzed the questionnaires conducted among student youth and its results. Theoretical - generalization of data collected during the research; empirical - observation, questionnaires, interviews; analyzed using the methods of the logical approach. Identified problems in the development of youth entrepreneurship and developed recommendations for their solution.

2181-1415/C) 2021 in Science LLC.

This is an open access article under the Attribution 4.0 International (CC BY 4.0) license (https://creativecommons.org/licenses/by/4.0/deed.ru)

\section{Талабаларда тадбиркорлик малакасини ривожлантириш - ёшлар тадбиркорлиги муаммоларини бартараф этиш омили сифатида}

\author{
Калит сўзлар: \\ Ёшлар \\ Тадбиркорлик \\ Ёшлар тадбиркорлиги
}

\section{АННОТАЦИЯ}

Ёшлар бандлигини таъминлашда ёшлар
тадбиркорлигини ривожлантириш мухим масалалардан бири хисобланади. Бугунги кунда ёшлар ўртасида ўз-ўзини банд қилишга интилиш юқори бўлиб, ўзларини моддий

\footnotetext{
1 c.e.s., associate Professor of Management, Namangan Engineering and Technological Institute Namangan, Uzbekistan

${ }^{2}$ Assistant Professor of Economics Namangan Engineering and Technological Institute Namangan, Uzbekistan E-mail: ergasevafotima77@gmail.com
} 
Тадбиркорлик кўникмаси ва малакалари

Тадбиркорлик

фаолиятининг ўзига хос

хусусиятлари

Ёшлар тадбиркорлигини ривожлантиришни

қўллаб-қувватлаш

Тадқиқот

Муаммолар

Тавсиялар

Операциядан кейинги

асоратлар томондан мустақил таъминлашга харакат қиладилар. Мақолада мамлакатимиз ахолиси таркибида ёшларнинг улуши, тадбиркорлартаркибида ёш тадбиркорларнинг улуши кўрсатиб ўтилган. Тадқиқот давомида талаба ёшлар ўртасида ўтказилган анкета сўровлари ва унинг натижалари тахлил этилган. Тадқиқот жараёнида тўпланган маълумотлар назарий - умумлаштириш; эмпирик - кузатиш, анкеталаштириш, сухбат; мантиқий ёндашув усуллари ёрдамида тахлил этилди. Ёшлар тадбиркорлигини ривожлантиришдаги муаммолар аниқланиб, уларнинг ечими учун тавсиялар ишлаб чиқилди.

\section{Развитие предпринимательских навыков у студентов - как фактор преодоления проблем молодого} предпринимательства

Ключевые слова:
Молодежь
Предпринимательство
Молодежное
предпринимательство
Предпринимательские
навыки и умения
Особенности
предпринимательской
деятельности
Поддержка развития
молодежного
предпринимательства
Исследования
Проблемы
Рекомендации
Послеоперационные
осложнения

\section{АННОТАЦИЯ}

Развитие молодежного предпринимательства - один из важных вопросов в сфере занятости молодежи. Сегодня среди молодых людей велико стремление к самозанятости, и они стараются самостоятельно обеспечивать себя в финансовом отношении. В статье показана доля молодежи в населении нашей страны, доля молодых предпринимателей в структуре предпринимателей. В ходе исследования были проанализированы анкеты, проведенные среди студенческой молодежи и его результаты. Данные, собранные в ходе исследования, были проанализированы с использованием методов теоретического обобщения, эмпирического наблюдения, анкетирования, интервьюирования; проанализированы с использованием методов логического подхода. Выявлены проблемы в развитии молодежного предпринимательства и разработаны рекомендации по их решению.

\section{КИРИШ}

Ёшларни иш билан таъминлаш муаммолари асосан - мамлакат саноатининг ривожланиш даражаси, ижтимоий-иқтисодий сохадаги ўзгаришлар, демографик вазиятнинг холати, соғлиғининг жисмоний ва рухий холатининг ўзгариши, стандартларнинг пасайиши ахолининг хаёти ва ижтимоий-иқтисодий омилларнинг ёшлар турмуш тарзига таъсири каби объектив жараёнлар билан боғлиқ.

Одатда, 25 ёшдан 30 ёшгача бўлган ёшлар аллақачон касбий стратегиясини белгилаб олган ва маълум бир иш тажрибасига эга бўладилар. Хаётларининг шу даврида, уларнинг аксариятини аллақачон оиласи бор ва улар таклиф қилинган иш учун юқори талабларни қўя бошлайдилар. Ёшлар мехнатига паст бахо бериш, мехнат адаптациясидаги муаммолари, мехнат фаолияти мотивациясини қониқарсизлиги каби муаммолар сабабли ёшлар орасида янги иш жойларини 
топиш қийин бўлиши мумкин. Шу билан бирга, ахолининг ушбу тоифаси томонидан ишнинг етишмаслиги жуда оғриқли тарзда қабул қилинади ва оғир ижтимоий, психологик оқибатларга олиб келиши мумкин[1].

Хозирги кунда мамлакатимизда расман иш билан банд бўлмаган 1 миллион 400 мингга яқин аёллар ва ёшлар бор. Хотин-қизлар ўртасида ишсизлик даражаси 13 фоиз, ёшларда эса 15 фоизни ташкил этмоқда. Фарғона, Самарқанд, Андижон, Қашқадарё ва Тошкент вилоятларида бу кўрсаткич юқори. Шу билан бирга, бугунги кунда қурилишда 104 минг, коммунал сохада 71 минг, хизмат кўрсатиш сохасида 68 минг, енгил саноатда 46 минг нафар мутахассисга эхтиёж мавжуд[2].

Бундай холатда ёшлардаги ишсизликнинг салбий оқибатларини олдини олиш учун уларни иш билан таъминлаш асосий муаммолардан биридир. Хозирда мамлакатимизда 15-29 ёшдагиларнинг сони 8,66 млн.нафарни ёки мамлакат ахолисининг 25,5 фоизини ташкил қилмоқда.

Илмий тадқиқотлар шуни кўрсатадики, мехнатга лаёқатли ахолининг 10-15 фоизидан кўпроғи тадбиркор бўлишга мойил. Бироқ, тадбиркорлик фаолияти учун қобилияти мавжуд бўлса, солиқ ва бошқа давлат қонунлари доирасида имтиёзлар бўлса, қўллаб-қувватлаш йўллари тўғрисида хабардор бўлса янада кўпроқ ёшлар тадбиркор бўлишни истайди.

Шу билан биргаликда, талабаларда тадбиркорлик кўникма ва малакаларини ривожлантиришда янги билимларни берибгина қолмай, балки ўзгарувчан рақобат шароитида муваффақиятли бизнес учун зарур бўлган фазилатлар хам шакллантирилади.

Бундан келиб чиқиб шуни таъкидлаш мумкинки, ёшлар билан олиб бориладиган ижтимоий-иқтисодий ишлар бугунги кундаги долзарб бўлиб, ёшларни мехнат фаолиятига максимал даражада жалб қилиш ва уларнинг бандлигини оширишни тақазо этади. Стратегик нуқтаи назардан, мамлакатимизнинг молиявий, ижтимоий, иқтисодий, илмий ресурсларни оширишга қодир ёшларни тайёрлаш давр талаби бўлиб, унда бозор иқтисодиёти шароитида ёшларнинг тадбиркорлик кўникма ва малакаларини ривожлантириш хамда, ахолининг ўз-ўзини иш билан таъминлашни қўллаб-қувватлашга эътибор бериш, бу борадаги муаммоларни бартараф этиш мухим вазифалардан эканлигини ифодалайди.

\section{МАВЗУГА ОИД АДАБИЁТЛАР ТАХЛИЛИ}

Ёшлар тадбиркорлигини ривожлантириш - кичик бизнес ва хусусий тадбиркорликни ривожлантиришнинг зарур стратегик манбаси хисобланади десак муболаға қилмаган бўламиз. Бугунги иқтисодий-ижтимоий ривожланиш ёшлар олдига ижтимоий институтлар билан биргаликда иқтисодий, сиёсий ва маънавий сохаларда ўзаро алоқада фаол иштирок этиш вазифаларини қўймоқда. Ёшлар тадбиркорлиги, уларни ташкил этиш ва ривожлантириш, бу борада ёшларнинг кўникма ва малакаларини ривожлантиришга хос ёндашувлар борасида қатор олимлар тадқиқот ишларини олиб борганлар.

Тадбиркорлик субъектлари таркибига —тадбиркорлик ва даромад келтирадиган мехнат фаолияти билан шуғулланиш истагида бўлган ёшлар тадбиркорлиги субъектлари хисобланган 18 ёшга тўлган 30 ёшдан ошмаган ёшлар хам киради[3]. 
Лекин ёшлар тадбиркорлигини тадқиқ этган адабиётлар ўрганилганда 15 ёшдан 35 ёшгача бўлган ёшлар хам бу қатламга киритилиб ўрганилганлигини кузатишимиз мумкин.

Шахмометьева М.Р. кичик ва ўрта бизнесни ривожлантириш учун зарур стратегик манба бу ёшлар тадбиркорлиги[4] эканлигини ўз илмий ёндашувида ёритиб ўтган.

Бозорнинг қаттиқ рақобати шароитида ёш фуқаролар ўз бизнесини ташкил этиш ва ўз-ўзини иш билан таъминлашни ривожлантириш истиқболлари хақида тобора кўпроқ ўйлашмоқда. Ёшлар ишчи кучининг энг истиқболли тоифасидир. Давлатда амалга оширилаётган сиёсатнинг изчиллиги минтақавий ва муниципал даражаларда кўп жихатдан ёшлар тадбиркорлик фаолияти иштирокига боғлиқ[5] дея ўз фикрини баён этади Меркулов П.А.

Сўнгги йилларда етакчи мамлакатлар иқтисодиётида ёшлар ишсизлиги кескин муаммо бўлиб қолмоқда. Бу глобал муаммони ечишда ёшлар тадбиркорлиги асосий восита бўлгани учун мухим ўрин тутади. Статистик кўрсаткичларга кўра, дунё бўйича 18 дан 30 ёшгача бўлган тахминан 300 миллион ёшларнинг доимий иш жойлари йўқ ёки умуман ишсизлардир[6].

Е.Г Шумикнинг фикрига кўра эса, ёшлар тадбиркорлиги кичик ва ўрта бизнес ривожланиши хисобига иқтисодий ривожланишнинг драйвери бўлиши, федерал бюджетни тўлдириши, шунингдек, инновацион ғояларни амалга ошириши мумкин...Шу билан бирга, ушбу тоифадаги фуқаролар ўз бизнесларини бошлаш ва ривожлантиришда ўзига хос муаммоларга дуч келишади. Ёшлар тадбиркорлигининг энг муқим томонларини аниқлаш жараёнида, ёшлар тадбиркорлигининг ривожланишига тўсқинлик қиладиган муаммоларнинг учта гурухи мавжуд: шахсий ёки мотивацион; тажриба ва касбий билимларнинг етишмаслиги; қонун чиқариш[7].

Ларичева А.А., Петрище В.И., Симонов С.Г., Грошева Л.И. ва Костырева Д.Э. ларнинг таърифича, тадбиркорлик сохасида - тажриба, профессионал ва аниқ билимларнинг етишмаслиги, қўллаб-қувватлашда дуч келадиган муаммолар бор.

Таълим назарий асосни яратади, аммо амалиёт хақида гап кетганда, кўпчилик қаердан бошлашни билмайди... Тадбиркорликни қўллаб-қувватлаш институтлари фаолияти хам ёшлар бизнесини ривожлантиришга етарлича йуналтирилмаган. Бу ерда шуни таъкидлаш керакки, ёш тадбиркорларни қўллаб-қувватлаш ривожланиш механизмини ишлаб чиқиш керак[8].

Демак, ёшлар тадбиркорлигини ривожлантиришда уларда тадбиркорлик билим, кўникма ва малакаларини етишмаслиги муаммосига дуч келинмоқда. Тадбиркорлик кўникма ва малакасини ривожлантириш провардда талабаларда тадбиркорлик фаолиятини қандай ташкил этиш, ундаги юзага келиши мумкин бўлган муаммоларни еча олишига имкон яратади деб ўйлаймиз.

\section{ТАДҚИҚОТ МЕТОДОЛОГИЯСИ}

Тадқиқот ишида ёшлар тадбиркорлиги бўйича маълумотлар шакллантирилди, ўрганилди. Тўпланган маълумотлар асосида назарий умумлаштириш; эмпирик - кузатиш, анкеталаштириш, сухбат; мантиқий ёндашув усуллардан фойдаланилди. 


\section{ТАХЛИЛ ВА НАТИЖАЛАР}

Тадбиркорлик фаолияти бу - таваккалчилик асосида ишлаб чиқариш омилларидан самарали фойдаланиш жараёни бўлиб, унда инноваторлик, ишбилармонлик, махсус қобилиятларни тўла ишга солган холда юқори ижтимоий, иқтисодий самарага эришиш хисобланади.

Бу борада замонавий билим ва кўникмаларга эга, мамлакатнинг муносиб келажаги учун жавобгарликни узз зиммасига ола биладиган баркамол мақсадга интилувчан ва серғайрат ёшларни тарбиялаш мамлакатни барқарор ва илдам ривожлантиришнинг энг мухим шартидир[9].

Республикада фаолият юритаётган тадбиркорлик субъектларининг 22,9 фоизи (106 минг 574 таси) 30 ёшгача бўлган ёшлар хиссасига тўғри келади. Якка тартибдаги тадбиркорларнинг 21,5 фоизини (71 минг 467 тани) 30 ёшгача бўлган ёшлар ташкил этади. Шунингдек, мамлакатда 3,4 мингга яқин ёш фермерлар, 7,8 мингга яқин ёш хунармандлар фаолият юритади[10].

Мамлакатимизда бугунги кун ёшларига алоқида эътибор берилиб, уларга бир қатор имтиёзлар берилмоқда, билим олишлари ва тадбиркорлик фаолиятлари бошлаш ва олиб бориш учун қулайликлар, керакли шарт-шароитлар яратилмоқда. Жумладан, “Ёшлар кичик саноат зоналари”ни ташкил этилиши, “Лойихалар фабрика"лари, “Ёшлар мурожаати” электрон платформаси, оилавий тадбиркорликни ривожлантириш борасида имтиёзли кредитлар бериш, ёшларнинг илғор ғоялари асосида лойихавий таклиф ва бизнес режаларини тайёрлаб бериш каби чора-тадбирларни амалга ошириш шулар жумласига киради[11].

Олиб бораётган тадқиқот ишларимизнинг тахлили шуни кўрсатмоқдаки, бугунги кун ёшларида ўз-ўзини мустақил моддий томондан таъминлаш истаги жуда юқоридир. Уларда тадбиркорлик фаолиятини ташкил этиш ғояларини мавжудлиги, бу фаолиятни қайси сохалар доирасида олиб бориш бўйича мустақил фикрга эгалар. Тадбиркорлик фаолиятларини ташкил этишга кўпроқ ўзларидаги мустақил моддий таъминотни йўлга қўйиш истаги, оила аъзоларининг фикри, бошқа дўстлари билан бўлган сухбатлари, олийгохдаги талабалар билан бўлган мушохадаларни сабаб қилиб кўрсатмоқдалар. Бу туғилган ғояларни амалга ошириш учун тули фаолиятларда даромад кўришни режалаштирганлар. Жумладан, ишлаб чиқариш ва хизмат кўрсатиш сохаларида $\downarrow$ нон ва нон махсулотлари, гўшт ва гўшт махсулотлари, қандолат, макарон махсулотлари ишлаб чиқариш, сут ва сут махсулотлари қайта ишлаш, писта қадоқлаш, умумий овқатланиш хизматлари, бедана гўшти ва тухумини етиштириш, паррандачилик, чорвачилик, балиқчилик, асаларичилик, боғдорчилик, қуёнчилик, иссиқхоналар ташкил этиш, гуллар етиштириш, ёғоч ва алюмин профилдан эшик ва деразалар, мебель, баннерлар ишлаб чиқариш, пахтани қайта ишлаш, гўзаллик салони, сартарошхона, спорт секциялари ва фитнес клублар ташкил этиш, фото ва видео хизматларини ташкил этиш, дизайнерлик, тайёр кийимлар тикиш, компьютер хизматларини кўрсатиш, заргарлик буюмларини таъмирлаш, маиший хизматлар ташкил этиш, маиший техника таъмирлаш, автосервис хизматлари, велосипедлар ижараси, пайвандлаш хизматлари, ўқув маркази ташкил этиш, ахоли учун агротехника хизмати, етказиб бериш хизмати, телефон таъмирлаш, бухгалтерия хисоби ва аудит хизмати, «Ёш тадбиркорлар» коворкинг маркази, “Ёшлар мехнат гузари” мажмуасини ташкил 
этиш ва бошқа шу каби фаолиятни ташкил этиш, даромадларини шакллантиришни мақсад қилиб қўйганлар[12].

Ёшлар тадбиркорлигини ривожлантиришни қўллаб-қувватлаш зарур, чунки ёшлар жамиятнинг динамик қисми бўлгани учун тадбиркорликда керакли салохиятни ташкил қиладилар. Ёшлар тадбиркорлигида бироз мураккаблик томони борки, бу сохада ёшлар сиёсати масалалари билан шуғулланувчи хокимият органлари томонидан алохида эътибор талаб этилади. Таъкидлаш жоизки, ёшларнинг асосий қисми олий ўқув юртида тўпланган. Талаба-бу мустақил хаёт остонасидаги шахс бўлиб, у ўз хусусий ишини ташкил этиш орқали ўзига ишонч йўлини очиши мумкин.

Бироқ, мамлакатимизда ёшлар хам тадбиркорлик фаолиятини ташкил этишда харажатлар, масъулият ва рақобат билан боғлиқ қийинчиликларга, дуч келмоқда. Яъни, ёшлар тадбиркорлик фаолиятларини бошлашда фақат ғоя билан чекланяптилар, холос. Айрим ёшларимиз берилган имкониятдан мақсадли фойдаланишни билмайдилар. Махсулотига бозор топишда қийинчиликларга дуч келяпти, шунингдек, ёш тадбиркорларнинг маълум қисми фаолиятини муддатидан олдин тўхтатишга мажбур бўляпти.

Тадқиқот маълумотларни тахлил қилиш натижасида иқтисодиёт таълим сохасидаги 18-26 ёшдаги талабаларнинг тадбиркорлик бўйича кўникма ва малакалари, тадбиркорлигини ташкил этиши бўйича фаоллиги аниқланди.

Тадқиқотда жами 437 киши иштирок этди. Тадқиқот жараёнида иштирокчилардан қуйидаги саволларга фикр билдиришлари сўралди:

1.Сизда тадбиркорликни бошлаш ғоясини шакллантирган манбани кўрсатинг.

2.Қайси сохаларда тадбиркорлик билан шуғулланишни режалаштиргансиз?

3. Сизнингча, ёшлар учун ўз бизнесини бошлаш осонми?

4. Ўз бизнес ғоянгиздан воз кечишнинг мумкин бўлган сабаблари?

- молиявий маблағни етишмаслиги;

- таваккалчиликдан қўрқиш;

- ўз бизнесингизни бошлаш учун етарли билимни ва тажрибани йўқлиги;

- давлат тадбиркорликни заиф қўллаб-қувватлайди

5. Бошланғич тадбиркорларни давлат томонидан қўллаб-қувватлаш чоралари хақида биласизми?

6.Ўз бизнесингизни очишда давлат кўмагидан фойдаланишни режалаштиряпсизми?

7. Нима учун тадбиркорлик кўникма ва малакаларини эгалламоқдасиз ёки эгалламоқчисиз? Тадбиркорлик билан шуғулланишга нима туртки бўляпти?

8. Сизнинг фикрингизча бугунги кунда қайси фаолият сохасига талаб кўп бўлмоқда?

Сўровномада иштирок этувчиларнинг жинси ва ёши хақида маълумотларни қолдиришлари сўралган бўлиб, бунга керакли маълумотларни белгилаганлар.Сўровномага жавоб берганларнинг 6 фоизи ёки 26 нафари аёллардир, 94 фоизи ёки 411 нафари эркаклардир. Иштирок этганларнинг уртача ёши 22 ёшни ташкил қилди.

Талаба ёшларда тадбиркорлик фаолиятини бошлаш ғоясини шакллантирган манбага олийгохдан ташқаридаги дўстлари (29,8 \%), оила аъзолари $(19,1 \%)$, 
оммавий ахборот воситалари, медиалар (газета, журнал, радио, телевидения, интернет ва шу каби бошқалар) (17 \%), тадбиркорликка оид аввалги лойихалар $(16,1 \%)$ ва бошқалар(18\%)ни кўрсатиб ўтганлар.

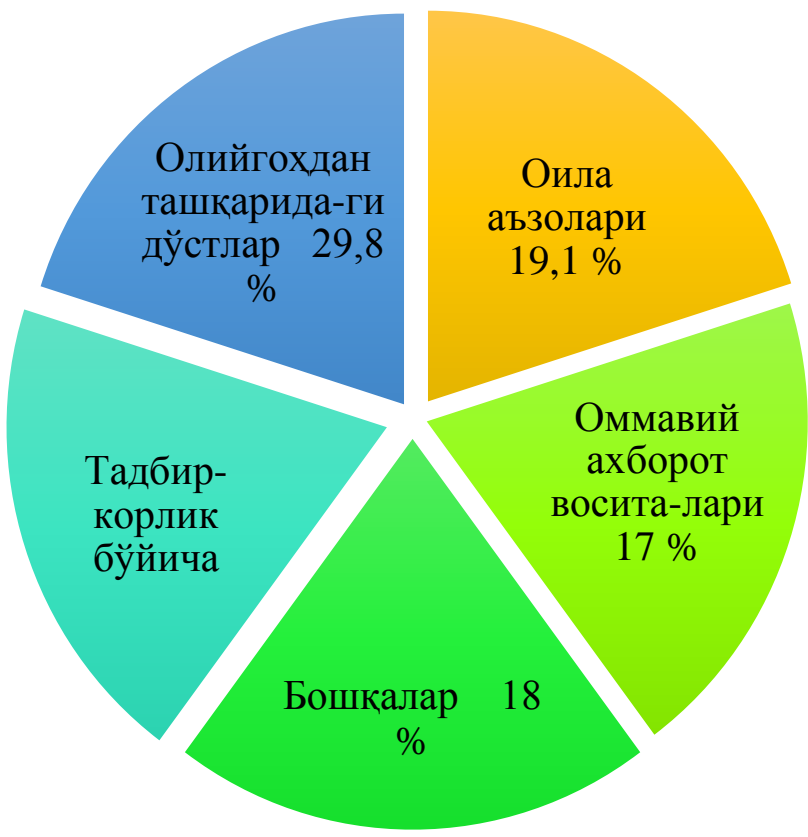

1-расм.Талабаларда тадбиркорлик фаолиятини олиб бориш ғоясини шакллантирган манбалар.

Талаба ёшларни қайси сохада тадбиркорлик қилишни режалаштирганликларини сўралганда, уларнинг аксарияти ишлаб чиқариш сохаларида (32,6 \%), савдо сохасида (24 5\%), қишлоқ хўжалик сохасида (19,8 \%), молиявий хизматлар кўрсатишда (7,4 \%), маркетинг, дизайн йўналишида (4,9\%) ва бошқа бир қатор сохаларда $(10,8 \%)$ тадбиркорлик фаолиятини ташкил этишни режалаштирганликларини билдирганлар.

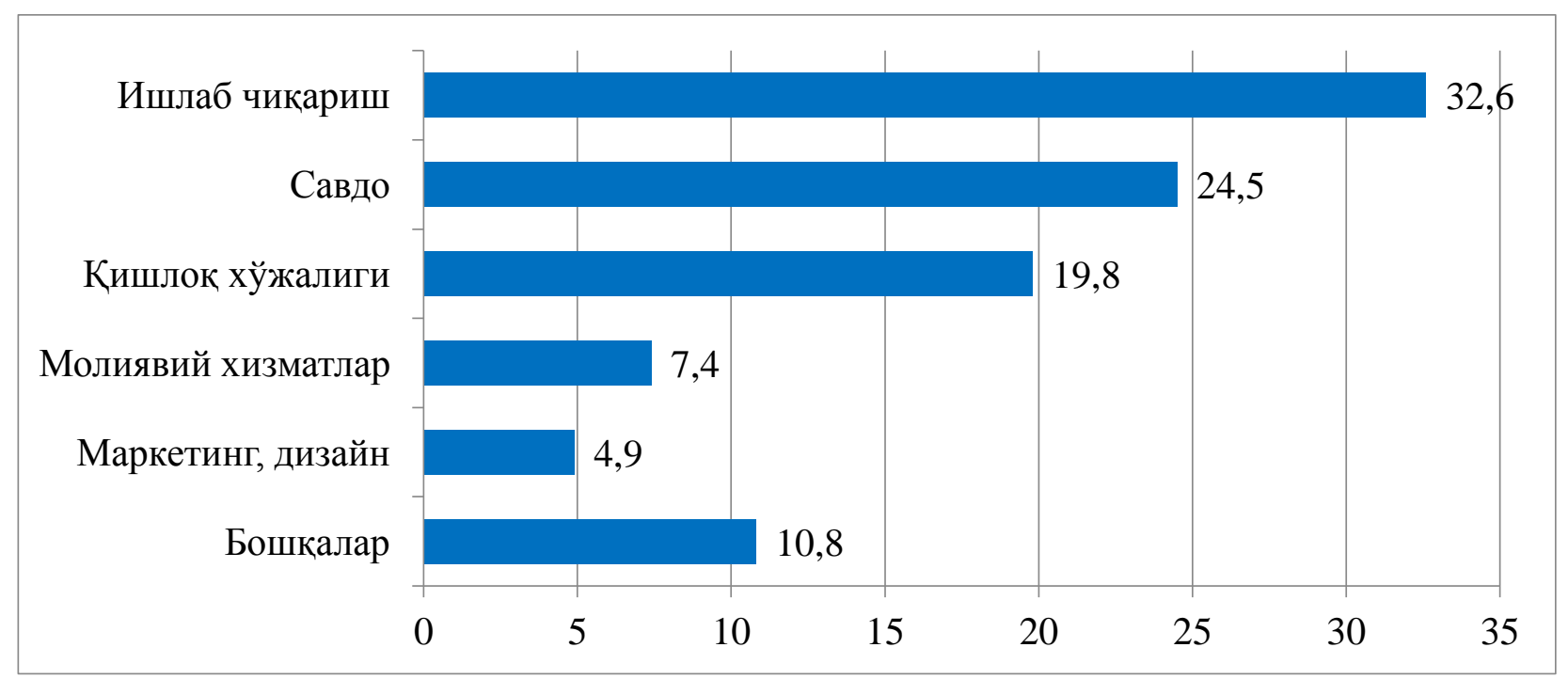

2-расм. Талаба ёшларни тадбиркорлик қилишни режалаштирган сохалари 
Талаба ёшларга ўз бизнесини бошлаш осонми, деган саволга кўпчилик салбий жавоб берган. Респондентларнинг 64 фоизи ёшлар учун тадбиркорлик фаолиятини бошлаш қийин деб хисоблайдилар. Улар бунга иккита асосий сабабни - биринчиси бизнес фаолиятини бошлаш учун сармояни етишмаслиги, иккинчиси бу сохада мустақил билим, кўникма, малака ва тажрибани етишмаслигини кўрсатиб ўтганлар.

Ёшлар ўз бизнес ғоясидан воз кечиши мумкинми, агар мумкин бўлса унинг сабабларини нималарда деб билишини сўралганда, аксарият қисми фаолиятни ташкил этиш ва бошлаш учун молиявий маблағни етишмаслиги (48\%), таваккалчилик қилишга қўрқиш (19,5 \%), малака ва тажрибани етишмаслиги $(30,5$ \%) ва бошқалар(2 \%)ни кўрсатиб ўтганлар.

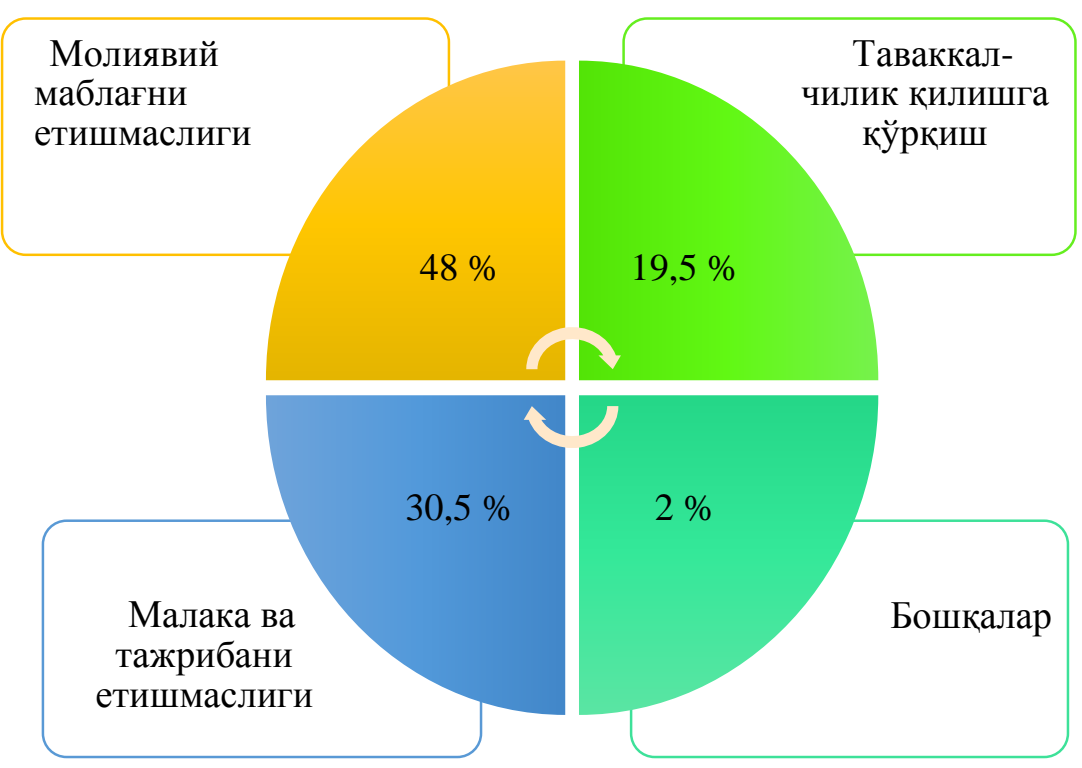

3-расм. Ёшларни ўз бизнес ғоясидан воз кечиши мумкин сабаблар

Бошланғич тадбиркорларни давлат томонидан қўллаб-қувватлаш чоралари хақида биласизми ва ўз бизнесингизни очишда давлат кўмагидан фойдаланишни режалаштиряпсизми деган саволларимизга респондентлар 52 фоизи бундай давлат томонидан қўллаб-қувватлаш чоралари мавжудлиги тўғрисида маълумотга эга. Қолган 48\% мавжуд имкониятлардан бехабар.

Давлат томонидан қўллаб-қувватлаш чоралари тўғрисида маълумотга эга бўлган респондентларнинг 64 фоизи келажакда ушбу имкониятлардан фойдаланишни режалаштирган, қолган 36 фоизи салбий жавоб берган.

Умуман олганда, бошланғич тадбиркорларни давлат томонидан қўллабқувватлаш чораларини қўллаш истиқболлари тўғрисида саволга жавоб берганларнинг барчаси ижобий фикр билдириб, қўллаб-қувватлаш воситаларидан фойдаланишга тайёр.

Талаба ёшлардан нима учун тадбиркорлик кўникма ва малакасини эгалламоқчисиз деган саволга улар томонидан қуйидагича жавоблар берилган:

- шахсий хаётни яхшилаш ва (ёки) бадавлат бўлиш - 26,7 \%;

- ўзгарувчан иш вақтига эга бўлиш истаги - инсон ўзига ёқадиган ишни, ўзи хохлаган пайтда бажариш эркинлиги - 18,9 \%;

- қўшимча даромад олиш ва сармоя йиғиш, мисол учун кўчмас мулк шаклида$16,7 \%$; 
- бўш вақтни иш билан банд қилиш (зерикишдан қочиш) - 7,8\%;

- ўқишни тугатиш вақтида даромад кўрадиган ишни топа олмаслигим эхтимоллигини юқорилиги - 15,6\% ва бошқалар (14,3\%) деб жавоб берганлар.

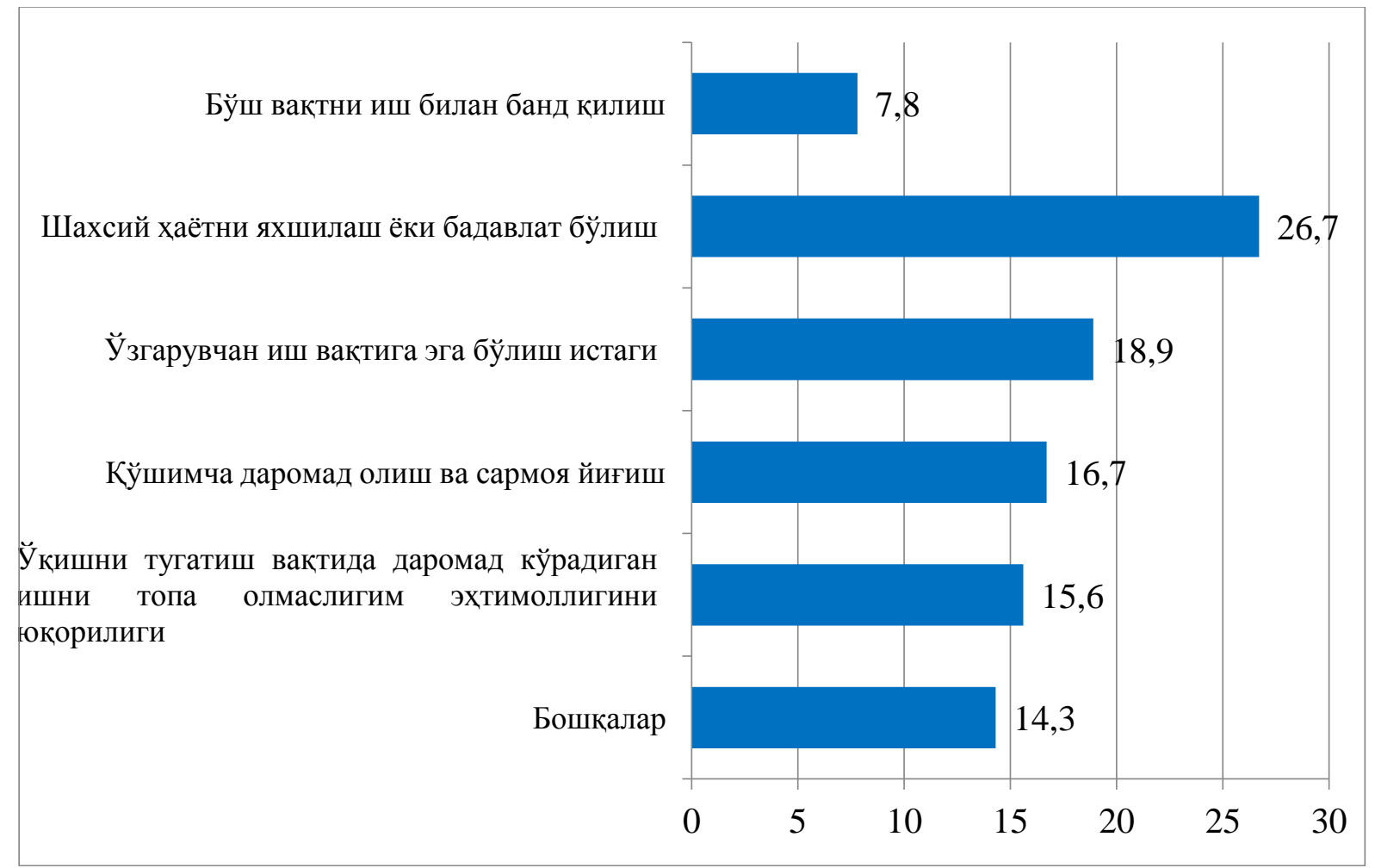

\footnotetext{
4-расм. Талаба ёшларни тадбиркорлик кўникма ва малакасини эгаллаш сабаблари
}

Сўровномадаги саволлардан бири респондент нуқтаи назаридан энг кўп талаб қилинадиган фаолият сохаларига - ахборот технологиялари сохаси, умумий овқатланиш ва қурилиш сохалари, гўзаллик салонлари, психолог маслахатлари, онлайн маслахат бериш хизматларини кўрсатиб ўтганлар.

Юқоридаги тадқиқот кўрсаткичлари натижаси шуни кўрсатмоқдаки, ёшларни ўз тадбиркорлик фаолиятини ташкил этишда қуйидаги муаммолар мавжуд:

- тадбиркорлик фаолиятини ташкил этиш борасида билим, кўникма, малака ва тажрибани етишмаслигини;

- ёшларда тадбиркорлик фаолиятига доир вазиятлар тўғрисида тор тасаввурларни эгалиги;

- ёшлар тадбиркорлигида банклар томонидан бериладиган кредит муддатлари чўзилиб кетиши, паст фоизли кредитларга эхтиёжни катталиги;

- ёшларни мавжуд имкониятлардан хабардорлик даражаси пастлиги, қўллабқувватлаш борасидаги маълумотларнинг етишмаслиги;

- ёшлар тадбиркорлигини қўллаб-қувватлаш инфратузилмасининг самарасини пастлиги;

- ёшлар тадбиркорлигини ахборот билан қўллаб-қувватлашни ривожланмаганлиги ва бошқалар. 
Пайдо бўлган муаммоларни хал қилиш мамлакатимизда қулай ишбилармонлик мухитини яратишга ва мамлакатнинг иқтисодий ўсишига қаратилган давлатнинг устувор мақсадларига эришишга ёрдам беради.

Талабаларда тадбиркорлик фаолиятларини ташкил этишни ривожлантириш учун талабаларнинг онгида тадбиркорнинг ижобий қиёфасини яратиш керак, бу эса таълим муассасасининг битирувчиларнинг келажакдаги ривожланишига қизиқиши билан кўпроқ боғлиқдир. Таъкидлаш жоизки, олийгох рахбарияти битирувчиларни ривожлантиришга қизиқиш билдирмоқда, бу нафақат маънавий ва хиссий мамнуниятга, балки олийгох рейтингини хамда, рақобатбардошлигини оширишда ахамияти каттадир.

\section{ХУЛОСА ВА ТАКЛИФЛАР}

Шундай қилиб, ёш авлод ва уларнинг тадбиркорлик фаолиятларини қўллабқувватлаш, ёшларда тадиркорлик кўникма ва малакасини ривожлантириш орқали тадбиркорлик фаолиятини ташкил этишнинг хозирги холати бўйича тахлилий материаллар ўрганиш натижалари, бизга бир нечта хулосалар қилиш имконини берди.

Талабаларда тадбиркорлик кўникма ва малакасини ривожлантириш орқали тадбиркорлик фаолиятини ташкил этиш, бундаги муаммоларни бартараф этиш учун қуйидагиларни тавсия этамиз:

- талабаларни тадбиркорлик фаолияти билан шуғулланишни ривожлантиришда жамоат ташкилотлари, давлат органлари билан хамкорлик қилишни ривожлантириш керак;

- таълим ва тадбиркорлик, талабалардаги ижодий фаолиятни бирлаштириш лозим; бунинг бажарилиш моделини ишлаб чиқиш ва таълимга тадбиқ қилиш, буни таълим жараёнига босқичма-босқич киритиш;

- тадбиркорлик ғояларини амалга оширишда лойихалар ишлаб чиқиш кўникма ва малакасини ривожлантириш;

- ишбилармон тадбиркорларга бириктириш, иш жараёнларини ўргатиш;

- ёшларни тадбиркорлик фаолиятини ташкил этиш ва олиб бориш учун керакли инфраструктураларни ривожлантириш, ёшларда улар билан ишлаш кўникма ва малакасини ривожлантириш;

- талаба ёшларда ахборот технологияларида ишлаш кўникма ва малакасини ривожлантириш, тадбиркорлик фаолиятида ахборот технологияларидан самарали фойдаланиш, иш вақтини тежаш, ортиқча йўл ва қоғоз харажатлари кескин қисқартиришни шакллантириш;

- ёшларнинг тадбиркорликдаги янги ғояларни амалга оширишга мотивлаштириш;

- тадбиркорлик сохасида фаол таълим-тарбия ишларини олиб бориш орқали ва шу кабилар.

\section{ФОЙДАЛАНИЛГАН АДАБИЁТЛАР РЎЙХАТИ}


1. Лапа Е.А. Использование инновационных педагогических технологий при подготовке студентов к предпринимательской деятельности. Ученые записки ЗабГГПУ. C-110. https://cyberleninka.ru/article/n/

2. Мирзаева Г. Тадбиркорликни ривожлантириш ва касбга тайёрлаш орқали камбағалликни камайтириш чоралари белгиланди.29.02.2020. https://tma.uz/uz/2020/02/29.

3. Вазирлар Махкамасининг 2018 йил 16 августдаги “Ўзбекистон Ёшлар Иттифоқи хузуридаги «Yoshlar - kelajagimiz» жамғармаси фаолиятини ташкил этиш чора-тадбирлари тўғрисида"ги 669-сонли қарори.https://lex.uz/docs/3826820

4. Шахмометьева М.P Молодежное предпринимательство как фактор развития экономики России. https://scienceforum.ru/2014/article/2014002087.

5. Меркулов П.А.Молодежное предпринимательство как фактор устойчивого социально-экономического роста, Среднерусский вестник общественных наук.Том 12. №3. 2017. СЕРИЯ: ЭКОНОМИКА.с-43

6. Лопатина Р.Ф. Социально-культурные условия формирования мотивации студенческой молодежи к предпринимательской деятельности [Электронный ресурс] // Российская государственная библиотека: [сайт]. - URL: http://dlib.rsl.ru/01006751585

7. Шумик Е.Г., Белик Е.В., Блинов М.П..Молодежное предпринимательство: проблемы и пути решения.

8. Ларичева А.А. Молодежное предпринимательство как фактор инновационного развития экономики России// XVIII ЦАРСКОСЕЛЬСКИЕ ЧТЕНИЯ/ под общ. ред. проф. В.Н. Скворцова; редакционная коллегия: проф. Т.А. Бороненко, доц. Л.Л. Букин, доц. Д.Ю. Гришин, проф. Л.М. Кобрина(отв. ред.), проф. Т.С. Комиссарова, проф. Н.М. Космачева, доц. А.М. Макарский, проф. А.Г. Маклаков, проф. Т.В. Мальцева, доц. Е.С. Нарышкина. СПб., 2014. С. 97-102; Петрище В.И. Инновационная среда и молодежное предпринимательство: проблемы и перспективы развития// науч.-метод. электронный журн. «Концепт». 2015. Т. 13. С. 766-770; Симонов С.Г., Грошева Л.И. Молодежное предпринимательство в России: проблемы и перспективы развития// Акад. вестн. 2012. №2 (20). С. 39-44.

9. Ўзбекистон Республикаси Президентининг«Yoshlar — kelajagimiz» давлат дастури тўғрисидаги ПФ-5466-сонли фармони. 2018 йил 27 июнь. https://lex.uz/m/acts/3826820.

10. Ўзбекистон Республикаси Вазирлар Махкамасининг “Ўзбекистонда ёшларга оид давлат сиёсатини 2025 йилгача ривожлантириш концепциясини тасдиқлаш тўғрисида"ги 23-сонли қарори. https://lex.uz/ .

11. “Ёшлар - Ўзбекистоннинг энг катта бойлиги, бебахо хазинаси”. Ўзбекистон Республикаси Президенти Ш.М.Мирзиёевнинг Ўзбекистон ёшлари форумида сўзлаган нутқи. Халқ сўзи. 2020 йил 26 декабрь.www.xs.uz.

12. Дедажанов Б.Н., Эргашева Ф.И. Талаба ёшларда тадбиркорлик малакасини ривожлантиришнинг устунликлари ва муаммоларининг назарий жихатлари. XVIII Международная молодежная научно-практическая конференция “Актуальные вопросы развития современного общества, экономики и профессионального образования". 25.03.2020. 